F. Reprod. Fert. (1967) 13, 445-456

\title{
INDUCED INFERTILITY IN CATTLE BY ISO-IMMUNIZATION WITH SEMEN AND TESTIS*
}

\author{
A. C. MENGE \\ Department of Animal Sciences, New Jersey Agricultural Experiment Station, \\ Sussex, New Fersey, U.S.A. \\ (Received 25th April 1966)
}

\begin{abstract}
Summary. Iso-immunization of heifers with bull semen and homogenized testis combined with Freund's complete adjuvant resulted in an induced temporary infertility. Eleven heifers injected intradermally with semen and six heifers with testis required an average of $4 \cdot 11$ and $4 \cdot 83$ inseminations/conception, respectively, compared with nine control heifers which averaged $1 \cdot 11$ services/conception. Two heifers immunized with semen were slaughtered after eight and twelve unsuccessful inseminations, and an unfertilized ovum was recovered from each animal. Intra-uterine injection of semen and adjuvant caused nine heifers to require an average of 2.67 services/conception compared with an average of 1.0 for four control animals that had received intra-uterine injections of adjuvant and saline or adjuvant and rabbit semen. Four diagnosed pregnancies of the iso-immunized heifers underwent degeneration and an additional seven incidences of embryo loss were suspected from delays in return to oestrus after breeding. There was no evidence of embryo mortality in the control animals.

Specific sperm agglutinins were detected in the serum and uterine and vaginal secretions of the iso-immunized heifers. The fertility of a particular insemination appears to have been negatively associated with the serum titre of sperm agglutinins at the time.
\end{abstract}

\section{INTRODUCTION}

The occurrence of natural iso-immunization with seminal antigens has been suggested as one possible cause of female infertility in mammals. In rabbits, exposure of spermatozoa to a cattle antiserum formed against rabbit semen induced both fertilization failure and embryo mortality (Kiddy, Stone \& Casida, 1959), an exposure of young conceptuses to the antiserum also increased the mortality rate (Menge, Kiddy, Stone \& Casida, 1962). The ability of antibodies against semen to cause increased levels of fertilization failure and embryo death suggests this as one cause of infertility in cattle, which is characterized by increases in both of these factors (reviewed by Casida, 1961).

* Paper of the Journal Series, New Jersey Agricultural Experiment Station, Rutgers-The State University, New Brunswick. 
Attempts by Kiddy, Stone, Tyler \& Casida (1959) to induce infertility by systemic injections of bull semen and intra-uterine injections of bull blood failed in heifers. Infertility, however, did occur in heifers inseminated with semen treated with homologous antisemen serum (Menge, Stone, Tyler \& Casida, 1962).

Iso-immunization with semen or homogenized testis combined with an adjuvant has induced infertility in guinea-pigs (Katsh, 1959; Isojima, Graham \& Graham, 1959; Behrman, Otani, Porter \& Nakayama, 1963) and rabbits (Behrman \& Nakayama, 1965). In mice, lowered fertility was obtained following injections of spermatozoa alone (McLaren, 1964) and spermatozoa mixed with adjuvant (Edwards, 1964). Fertility in rabbits, however, was not affected by immunization with seminal plasma (Weil \& Roberts, 1965).

The present study was undertaken to determine the effects on fertility in heifers of iso-immunization with semen and testis combined with an adjuvant.

\section{MATERIALS AND METHODS}

Dairy-type heifers (thirty-four of Holstein breeding and eight of Guernsey breeding) with normal length oestrous cycles were used throughout the study. Twelve heifers were immunized against bull semen by intradermal injection. Six of the heifers received four injections, with the first three injections given at 2-week intervals and the final injection given 3 weeks after the third. In the remaining six heifers immunized with semen and in an additional six heifers immunized with testis a total of three injections were given. There was a 1- to 2week interval between the first two injections and a 3- to 4-week interval between the second and third injections. Each intradermal injection consisted of $2 \mathrm{ml}$ of the antigen-adjuvant material given at multiple sites in 0.1 to $0.2 \mathrm{ml}$ amounts. The semen-adjuvant mixture was prepared by emulsifying whole bull semen containing 1 or $2 \times 10^{9}$ spermatozoa $/ \mathrm{ml}$ with an equal volume of Freund's complete adjuvant. Semen was collected by an artificial vagina from two bulls and used immediately or kept frozen until used. The testis-adjuvant material was an emulsified mixture of homogenized testis diluted $1: 2$ with saline solution and Freund's complete adjuvant. The testes were from an adult bull that had been producing high quality semen before slaughter.

Intra-uterine injections of $2 \mathrm{ml}$ of the semen-adjuvant mixture were given to five heifers at two successive periods of oestrus and to six heifers at three successive periods of oestrus. Two of the six heifers had their oviducts ligated near the tubo-uterine junction with serrifine forceps through a supravaginal incision. The injections were administered on the 1st or 2nd day after oestrus in each case, and at the last injection $\mathrm{I} \times 10^{5}$ units of penicillin and $100 \mathrm{mg}$ dihydrostreptomycin sulphate were included in the injection material. Control animals consisted of two heifers that were given three intra-uterine injections of $2 \mathrm{ml}$ of an adjuvant-saline solution mixture and two heifers given three intra-uterine injections of $2 \mathrm{ml}$ of a rabbit semen-adjuvant mixture. As with the treated heifers the control animals also received the antibiotics with the last injection.

The heifers were bred starting at the first and second oestrous periods following the last injection in the intradermal and intra-uterine groups, respectively. 
The animals were artificially inseminated with $1 \mathrm{ml}$ of extended semen containing approximately $30 \times 10^{6}$ spermatozoa. The semen was collected with an artificial vagina from the two bulls whose semen had been used for the immunizations and was extended in a chemically defined medium referred to as Norman-Johnson (N-J) solution (Norman, Johnson, Porterfield, Goldberg \& Dunbar, 1961). Only semen samples with initial motilities of at least $60 \%$ were used for the inseminations. The ovaries and reproductive tracts of the heifers were examined regularly by rectal palpation to follow the occurrence of ovulations, abnormalities and pregnancies.

After two unsuccessful breedings, one of the six heifers (Heifer 17) given three intradermal injections of semen was fitted with an apparatus to collect uterine fluid according to the method described by Black, Duby \& Riesen (1963). A collecting tube, consisting of one polyethylene tube (outside diameter $2.4 \mathrm{~mm}$, inside diameter $1.7 \mathrm{~mm}$ ) inserted into another tube (outside diameter $3.5 \mathrm{~mm}$, inside diameter $2.7 \mathrm{~mm}$ ) was flanged at one end by heating. The animal was laparotomized in the right flank under local anaesthesia and the flanged end of the collecting tube was inserted into the uterine horn through a small incision at the tubo-uterine junction and sutured in place. The free end of the tube was exteriorized through an abdominal puncture in the lower right flank. The tube was attached to a collection vial which was fastened to the skin with a heavy synthetic suture.

Serum samples were obtained from the heifers by venous puncture before the first injection and at various times thereafter. Vaginal mucus samples were obtained on either the day of oestrus or the following day beginning before the first injection. The mucus samples were obtained from tampons of cotton and surgical gauze that had been inserted into the anterior vagina by use of a $25 \mathrm{~mm}$ diameter glass tube. Both the serum and mucus samples were heated at $56^{\circ} \mathrm{C}$ for $30 \mathrm{~min}$ before use in immunological tests. The titre of sperm agglutinins in the serum and mucus samples was determined by the gelatine agglutination method (Kibrick, Balding \& Merrill, 1953) as described in an earlier publication (Menge, Stone, Tyler \& Casida, 1962).

\section{RESULTS}

\section{EFFECT OF INTRADERMAL INJECTIONS}

The intradermal injections of semen and testis combined with adjuvant resulted in an induced infertility in the majority of the treated heifers (Table 1). The average number of inseminations required per diagnosed pregnancy in nine of twelve semen-immunized heifers which eventually became pregnant was 4.11 (range 1 to 8 ). A similar value of 4.83 (range 2 to 8 ) inseminations per pregnancy was observed in the six animals injected with testis. Considering all services in the group iso-immunized with semen, the average was 4.92 inseminations per animal, as Heifers 61 and 62 were inseminated unsuccessfully twelve and eight times, respectively. These heifers were slaughtered 3 days after their last insemination and an unfertilized ovum was recovered from the oviducts of each animal. The reproductive tracts of these two heifers appeared 
normal and were patent, as spermatozoa were found in the flushings from the oviduct.

Nine control heifers, which were exhibiting normal oestrous cycles, were artificially inseminated with the same semen and during the same period as the treated animals. Conception occurred after one insemination in eight of the heifers and after two services in the ninth animal.

TABLE 1

EFFEGT OF INTRADERMAL INJECTION OF SEMEN AND TESTIS ON FERTILITY IN HEIFERS

\begin{tabular}{|c|c|c|c|c|c|}
\hline \multirow{2}{*}{$\begin{array}{l}\text { Heifer } \\
\text { No. }\end{array}$} & \multirow{2}{*}{$\begin{array}{l}\text { No. of } \\
\text { injections }\end{array}$} & \multirow{2}{*}{$\begin{array}{l}\text { Inseminations| } \\
\text { conception }\end{array}$} & \multicolumn{3}{|c|}{ Oestrous cycle lengths (days) } \\
\hline & & & $\begin{array}{c}\text { Before } \\
\text { insemination }\end{array}$ & After inseminat & \\
\hline $\begin{array}{l}19 \\
24 \\
26 \\
27 \\
31 \\
32 \\
15 \\
17 \\
49 \\
54 \\
61 \\
62\end{array}$ & $\begin{array}{c}\text { Semen } \\
\text { injection } \\
4 \\
4 \\
4 \\
4 \\
4 \\
4 \\
3 \\
3 \\
3 \\
3 \\
3 \\
3\end{array}$ & $\begin{array}{c}5 \\
1 \\
5 \\
2 \\
6 \\
3^{*} \\
2 \\
2 \dagger \\
5 \\
8 \\
12 \ddagger \\
8 \ddagger \\
\text { Average } 4.11\end{array}$ & $\begin{array}{l}20,18,21 \\
18,19,20 \\
18,18,21 \\
23,18,39 \\
19,18,20 \\
19,21,21 \\
23,19,20 \\
21,20,22 \\
18,19,19 \\
20,21,19 \\
21,19,22 \\
21,24,19\end{array}$ & $\begin{array}{l}20,25,21,26 \\
- \\
20,24,16,19 \\
21 \\
19,20,19,20,20 \\
49,37 \\
21 \\
22,19 \\
18,19,17,18 \\
20,21,19,22,21,24,20 \\
20,21,19,21,19,20,19,21, \\
21,43,19 \\
19,19,23,22,22,20,22\end{array}$ & $\begin{array}{c}\text { Average } \\
\text { insemina- } \\
\text { tions/ } \\
\text { animal } \\
4.92\end{array}$ \\
\hline $\begin{array}{l}14 \\
18 \\
21 \\
29 \\
33 \\
46\end{array}$ & $\begin{array}{c}\text { Testis } \\
\text { injection } \\
3 \\
3 \\
3 \\
3 \\
3 \\
3\end{array}$ & $\begin{array}{c}3 \\
4 \\
2 \\
8 \\
8 \\
4 \\
\text { Average } 4.83\end{array}$ & $\begin{array}{l}17,19,22 \\
20,21,21 \\
23,18,19 \\
21,22,21 \\
18,21,18 \\
17,21,20\end{array}$ & $\begin{array}{l}17,22 \\
24,21,22 \\
28 \\
19,20,21,21,15,20,21 \\
22,20,22,21,21,21,21 \\
19,22,20\end{array}$ & \\
\hline \multicolumn{2}{|c|}{$\begin{array}{l}\text { Controls } \\
\text { Nine heifers }\end{array}$} & Average $1 \cdot 11$ & Range $17-23$ & $19 \$$ & \\
\hline
\end{tabular}

* Heifer diagnosed pregnant on Day 32 but conceptus lost before slaughter on Day 39 after insemination.

$\dagger$ After two unsuccessful inseminations a uterine catheter was inserted in this animal to collect uterine fluids.

$\$$ Unfertilized ovum recovered at slaughter 3 days after the last insemination.

$\$$ One control heifer returned to oestrus after first insemination.

In the experimental group, Heifers 18, 19 and 33 were sold after 2 months of pregnancy and Heifers 14, 15, 21, 49 and 54 were allowed to complete their pregnancy, whereas the remaining heifers in this group and six of the animals in the control group were slaughtered from 32 to 45 days after insemination. The exceptions to this were Heifers 61 and 62 as described above. Also three control heifers were sold after 2 months of pregnancy. Normal and viable embryos were obtained from each of the pregnant heifers that were slaughtered 
except for Heifer 32, which was diagnosed pregnant on Day 32 but did not have a conceptus at slaughter on Day 39 after insemination. The uterine horn of this heifer was enlarged and showed endometrial inflammation.

Prolonged oestrous cycles of 25 days or more occurred only once (Heifer 27) before insemination but six times in four heifers after breeding. The prolonged cycles of Heifers 27 and 61 and the 49-day cycle of Heifer 32 were apparently a result of silent or missed oestrous periods, as new ovulations occurred during these intervals. Heifer 32 apparently ovulated again between Days 28 and 32, whereas in the other two animals ovulation occurred between Days 20 and 25. However, during the prolonged cycles of three heifers new ovulations were not detected.

TABLE 2

REGIPROCAL OF TITRE OF SPERM AGGLUTININS IN SERA OF INTRADERMALLY INJECTED HEIFERS

\begin{tabular}{|c|c|c|c|c|c|c|c|c|c|c|c|c|c|}
\hline \multirow{2}{*}{$\begin{array}{l}\text { Heifer } \\
\text { No. }\end{array}$} & \multirow{2}{*}{$\begin{array}{c}\text { Normal } \\
\text { serum }\end{array}$} & \multicolumn{12}{|c|}{ Insemination number when immune serum samples obtained* } \\
\hline & & 1 & 2 & 3 & 4 & 5 & 6 & 7 & 8 & 9 & 10 & 11 & 12 \\
\hline \multicolumn{2}{|c|}{ Semen injection } & & & & & & & & & & & & \\
\hline $\begin{array}{l}19 \\
24\end{array}$ & $\begin{array}{r}16 \\
8\end{array}$ & $\begin{array}{r}512 \\
64\end{array}$ & 512 & 256 & 128 & 64 & & & & & & & \\
\hline 26 & 8 & 1024 & 512 & 256 & 256 & 128 & & & & & & & \\
\hline 27 & 8 & 64 & 32 & & & & & & & & & & \\
\hline 31 & 8 & 256 & 512 & 256 & 128 & 128 & 64 & & & & & & \\
\hline 32 & 8 & 256 & 128 & 64 & & & & & & & & & \\
\hline 15 & 16 & 256 & 64 & & & & & & & & & & \\
\hline 17 & 8 & 512 & 256 & & & & & & & & & & \\
\hline 49 & 8 & 512 & 256 & 128 & 64 & 32 & & & & & & & \\
\hline 54 & 16 & 512 & 512 & 128 & 128 & 256 & 64 & 64 & 32 & & & & \\
\hline 61 & 8 & 512 & 256 & 128 & 64 & 64 & 64 & 128 & 128 & 64 & 64 & 64 & 64 \\
\hline 62 & 16 & 512 & 512 & 256 & 128 & 256 & 128 & 64 & 64 & & & & \\
\hline \multicolumn{2}{|c|}{ Testis injection } & & & & & & & & & & & & \\
\hline & & 128 & & 64 & & & & & & & & & \\
\hline 18 & 8 & 128 & 128 & 128 & 32 & & & & & & & & \\
\hline 21 & 8 & 128 & 32 & & & & & & & & & & \\
\hline 29 & 8 & 256 & 512 & 256 & & 128 & 64 & 64 & 32 & & & & \\
\hline 33 & 8 & 512 & 256 & 128 & 128 & 64 & 64 & 32 & 32 & & & & \\
\hline 46 & 16 & 512 & 256 & 128 & 64 & & & & & & & & \\
\hline
\end{tabular}

* The last titre value in each row represents the insemination number at which conception occurred except for Heifer 17 which had a catheter placed into the uterus and for Heifers 61 and 62 which were slaughtered 3 days after the twelfth and eighth insemination respectively.

At the first insemination the titres of sperm agglutinins in the serum samples from the heifers immunized with semen ranged from $1: 64$ to $1: 1024$, and those of the testis-injected group from $1: 128$ to $1: 512$ (Table 2). This range illustrates the animal variation in response to the iso-immunizations. As would be expected, there was a general decrease in the antibody titre in the serum samples with an increasing number of inseminations. Serum samples taken at the time of the insemination from which pregnancy ensued possessed agglutinin titres of 1:64 or $1: 32$, except for Heifer 26 where the titre was $1: 128$. Sperm agglutinins were present in vaginal mucus samples obtained after semen immunization; the titres varied greatly, however, from sample to sample within animal and among 
animals. The titres ranged from less than $1: 2$ to $1: 128$ for the various mucus samples with no apparent association with the serum values, except that the mucus titres were never more than half the serum titres. Normal mucus samples had titres of less than $1: 2$ to $1: 4$.

The uterine secretions from Heifer 17 obtained with the indwelling collection tube were pooled to form 3-day samples. The tube was inserted on the day following oestrus and remained in place for one oestrous cycle (21 days). Samples from Days 1 to 3,4 to 6,7 to 9,10 to 12,13 to 15,16 to 18 and 19 to 21 were tested and found to have the following respective titres of sperm agglutinins: $1: 32,1: 16,1: 16,1: 8,1: 32,1: 128$ and $1: 128$. The heifer received an intradermal injection of $2 \mathrm{ml}$ of semen and adjuvant on Day 10 of the cycle, which resulted in an increase in serum titre from 1:128 on Day 1 to 1:256 on Day 21. The volume of uterine secretions collected daily averaged from 0.15 to $0.31 \mathrm{ml}$ for Days 1 to 17 , and from 0.5 to $1.0 \mathrm{ml}$ for Days 18 to 21 .

TABLE 3

EFFECT OF INTRA-UTERINE INJECTIONS OF SEMEN ON FERTILITY IN HEIFERS

\begin{tabular}{|c|c|c|c|c|}
\hline \multirow{2}{*}{$\begin{array}{l}\text { Heifer } \\
\text { No. }\end{array}$} & \multirow{2}{*}{$\begin{array}{c}\text { Noo. of } \\
\text { injections }\end{array}$} & \multirow{2}{*}{$\begin{array}{l}\text { Inseminations/ } \\
\text { conception }\end{array}$} & \multicolumn{2}{|c|}{ Oestrous cycle lengths (days) } \\
\hline & & & $\begin{array}{c}\text { Before } \\
\text { insemination }\end{array}$ & $\begin{array}{c}\text { After } \\
\text { insemination }\end{array}$ \\
\hline $\begin{array}{l}28 \\
41 \\
42 \\
47 \\
59 \\
44 \\
51 \\
56 \\
60\end{array}$ & $\begin{array}{l}2 \\
2 \\
2 \\
2 \\
2 \\
3 \\
3 \\
3 \\
3\end{array}$ & $\begin{array}{c}1 \\
4 \\
4^{*} \\
2 \\
1 \\
4 \\
2 \\
4 \\
2 \dagger \\
\text { Average } 2 \cdot 67\end{array}$ & $\begin{array}{l}20,20,21 \\
21,17,21 \\
21,18,24 \\
19,21,21 \\
21,16,18 \\
20,22,17 \\
18,17,18 \\
16,21,23 \\
20,18,22\end{array}$ & $\begin{array}{l}- \\
20,30,35 \\
24,21,21 \\
21 \\
- \\
40,21,16 \\
18 \\
21,59,20 \\
21\end{array}$ \\
\hline $\begin{array}{l}\text { Controus } \\
\text { Saline + adjuvant } \\
64 \\
65\end{array}$ & $\begin{array}{l}3 \\
3\end{array}$ & $\begin{array}{l}1 \\
1\end{array}$ & $\begin{array}{l}20,22,19 \\
18,19,17\end{array}$ & - \\
\hline $\begin{array}{c}\text { Rabbit semen }+ \text { ad } \\
66 \\
67\end{array}$ & $\begin{array}{r}\text { uvant } \\
3 \\
3\end{array}$ & $\begin{array}{c}1 \\
1 \\
\text { Average } 1 \cdot 00\end{array}$ & $\begin{array}{l}20,19,21 \\
19,22,20\end{array}$ & - \\
\hline
\end{tabular}

* Slaughtered on Day 37 after the fourth insemination; a severe pyometra was present in the uterus but no evidence of a conceptus.

† Degenerating conceptus found at slaughter on Day 42 after the second insemination.

\section{EFFEGT OF INTRA-UTERINE INJECTIONS}

The nine heifers which were bred after immunization with semen and adjuvant by the intra-uterine route required an average of 2.67 inseminations per pregnancy, compared to the four control animals each of which conceived after one insemination (Table 3). The two control heifers injected with rabbit semen were inseminated at the first oestrus after the last injection by mistake, 
instead of at the second oestrus as were the remaining controls and experimental animals.

The heifers of both the treated and untreated groups were slaughtered from 31 to 42 days after the insemination at which conception occurred, except in the case of Heifer 42. This animal was examined on Day 34 after fourth service and only fluids could be detected in the uterine horns. At slaughter on Day 37 a severe pyometra was present in the uterus without any signs of a conceptus. Regular rectal examinations of the ovaries revealed that this

TABLE 4

RECIPROCAL OF TITRE OF SPERM AGGLUTININS IN SERUM AND

VAGINAL MUGUS SAMPLES OF HEIFERS INJEGTED BY THE INTRA-UTERINE ROUTE

\begin{tabular}{|c|c|c|c|c|c|c|c|}
\hline \multirow[t]{2}{*}{ Heifer $\mathcal{N} o$} & \multirow[t]{2}{*}{ Sample* } & \multirow[t]{2}{*}{ Normal } & \multicolumn{5}{|c|}{$\begin{array}{l}\text { Insemination number when samples } \\
\text { obtained } \dagger\end{array}$} \\
\hline & & & 0 & 1 & 2 & 3 & 4 \\
\hline 28 & $\begin{array}{c}\mathbf{S} \\
\mathbf{M}\end{array}$ & $\begin{array}{r}16 \\
<2\end{array}$ & $\begin{array}{l}64 \\
64\end{array}$ & $\begin{array}{r}32 \\
8\end{array}$ & & & \\
\hline 41 & $\begin{array}{l}\mathbf{S} \\
\mathbf{M}\end{array}$ & $\begin{array}{r}16 \\
<2\end{array}$ & $\begin{array}{r}256 \\
64\end{array}$ & $\begin{array}{r}256 \\
64\end{array}$ & $\begin{array}{r}128 \\
8\end{array}$ & $\begin{array}{r}32 \\
2\end{array}$ & $\begin{array}{r}16 \\
4\end{array}$ \\
\hline 42 & $\underset{\mathbf{M}}{\mathbf{S}}$ & $\begin{array}{l}8 \\
2\end{array}$ & $\begin{array}{l}256 \\
128\end{array}$ & $\begin{array}{r}256 \\
32\end{array}$ & $\begin{array}{r}256 \\
16\end{array}$ & $\begin{array}{l}128 \\
<2\end{array}$ & $\begin{array}{r}64 \\
8\end{array}$ \\
\hline 47 & $\begin{array}{l}\mathbf{S} \\
\mathbf{M}\end{array}$ & $\begin{array}{r}16 \\
<2\end{array}$ & $\begin{array}{r}256 \\
64\end{array}$ & $\begin{array}{r}128 \\
8\end{array}$ & $\begin{array}{r}16 \\
<2\end{array}$ & & \\
\hline 59 & $\stackrel{\stackrel{S}{\mathbf{M}}}{\mathbf{M}}$ & $\begin{array}{l}8 \\
2\end{array}$ & $\begin{array}{r}64 \\
8\end{array}$ & $\begin{array}{r}16 \\
4\end{array}$ & & & \\
\hline 44 & $\underset{\mathbf{M}}{\mathbf{S}}$ & $\begin{array}{r}16 \\
<2\end{array}$ & $\begin{array}{r}128 \\
32\end{array}$ & $\begin{array}{r}64 \\
4\end{array}$ & $\begin{array}{l}64 \\
16\end{array}$ & $\begin{array}{r}32 \\
4\end{array}$ & $\begin{array}{r}16 \\
<2\end{array}$ \\
\hline 51 & $\stackrel{\mathrm{S}}{\mathrm{M}}$ & $\begin{array}{r}16 \\
2\end{array}$ & $\begin{array}{r}128 \\
8\end{array}$ & $\begin{array}{r}128 \\
4\end{array}$ & $\begin{array}{r}32 \\
2\end{array}$ & & \\
\hline 56 & $\stackrel{\mathbf{S}}{\mathbf{M}}$ & $\begin{array}{l}8 \\
4\end{array}$ & $\begin{array}{r}256 \\
64\end{array}$ & $\begin{array}{r}128 \\
16\end{array}$ & $\begin{array}{l}32 \\
32\end{array}$ & $\begin{array}{r}32 \\
<2\end{array}$ & $\begin{array}{r}16 \\
4\end{array}$ \\
\hline 60 & $\underset{\mathbf{M}}{\mathbf{S}}$ & $\begin{array}{r}8 \\
<2\end{array}$ & $\begin{array}{r}256 \\
16\end{array}$ & $\begin{array}{r}64 \\
4\end{array}$ & $\begin{array}{r}32 \\
4\end{array}$ & & \\
\hline Controls (4) $\ddagger$ & $\stackrel{\mathbf{S}}{\mathbf{M}}$ & $<2-2$ & $\begin{aligned} & 8-16 \\
&<2-4\end{aligned}$ & $\begin{array}{l}3-16 \\
2-2\end{array}$ & & & \\
\hline
\end{tabular}

* $\mathrm{S}=$ Serum samples; $\mathrm{M}=$ Mucus samples.

† 0 insemination number is the intervening oestrus between the oestrus of last treatment and the oestrus of first insemination. The last value in each row represents the breeding number at which conception occurred.

$\ddagger$ The two heifers injected with rabbit semen and adjuvant were inseminated at the first oestrus after treatment, whereas the other two controls were inseminated at the second oestrus following treatment.

animal had not re-ovulated between insemination and slaughter. Normal and viable conceptuses were recovered from the remaining heifers, except for Heifer 60 from which a degenerate conceptus was recovered on Day 42 after the second insemination.

None of the oestrous cycles before insemination in the experimental or control animals was greater than 24 days in length; however, four return cycles of three heifers after breeding were 30 days or more in length. The apparent 
return interval of 40 days for Heifer 44 was probably due to the failure to observe oestrus and ovulation which occurred about Day 20. During the intervals of 30 and 35 days of Heifer 41 new ovulations had not occurred. Heifer 56 experienced a cycle length of 59 days; during this time the animal was pronounced pregnant on Day 33 but subsequently lost the embryo, as a purulent discharge from the vulva was noted between Days 35 and 39. The heifer ovulated again, without an accompanying oestrus, between Days 38 and 43 , and then returned to oestrus and was inseminated again on Day 59.

The sperm-agglutinin titres of the serum and mucus samples from the heifers immunized with semen by the intra-uterine route are presented in Table 4. The titres increased from pre-injection levels of $1: 16$ or less to $1: 64$ to $1: 256$ in the serum samples, and from $1: 2$ or less up to $1: 64$ in the mucus

TABLE 5

REGIPROCAL TITRES OF SPERM AGGLUTININS IN THE SERUM AND VAGINAL MUGUS SAMPLES OF TWO HEIFERS WITH LIGATED OVIDUCTS FOLLOWING INTRA-UTERINE IMMUNIZATION WITH SEMEN

\begin{tabular}{|c|c|c|c|c|c|}
\hline \multirow{3}{*}{ Weeks } & \multirow{3}{*}{ Oestrus and injections } & \multicolumn{4}{|c|}{ Heifer $\mathcal{N}$ o. } \\
\hline & & \multicolumn{2}{|c|}{164} & \multicolumn{2}{|c|}{448} \\
\hline & & Serum & Mucus & Serum & Mucus \\
\hline $\begin{array}{l}0 \\
1\end{array}$ & Oestrus and injections & $\begin{array}{r}8 \\
16\end{array}$ & 2 & $\begin{array}{l}8 \\
8\end{array}$ & $<2$ \\
\hline 2 & 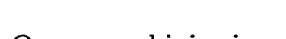 & 32 & & 16 & \\
\hline $\begin{array}{l}3 \\
4\end{array}$ & Oestrus and injections & $\begin{array}{l}32 \\
64\end{array}$ & 8 & $\begin{array}{l}16 \\
32\end{array}$ & 4 \\
\hline 5 & & 32 & & 16 & \\
\hline 6 & Oestrus and injections & $\begin{array}{l}16 \\
32\end{array}$ & 4 & $\begin{array}{l}16 \\
32\end{array}$ & 8 \\
\hline 9 & Oestrus and injections & 64 & 8 & 32 & 4 \\
\hline 10 & & 32 & & 32 & \\
\hline 12 & Oestrus and injections & 32 & 8 & 32 & 8 \\
\hline $\begin{array}{l}13 \\
15\end{array}$ & Oestrus and injections & $\begin{array}{l}64 \\
32\end{array}$ & 16 & $\begin{array}{l}04 \\
32\end{array}$ & 8 \\
\hline 16 & & 32 & & 16 & \\
\hline 18 & Oestrus and injections & 16 & 8 & 16 & 8 \\
\hline 21 & Oestrus & 32 & 16 & 32 & 16 \\
\hline
\end{tabular}

samples obtained at the first oestrus after injection. The serum titres decreased with increasing services until they were $1: 16$ or $1: 32$, when pregnancy occurred. There was a general trend for the antibody titres in the mucus samples to be associated with the serum titres within animals, although again they were quite variable. Serum and mucus samples from the control heifers had titres of bull-sperm agglutinins similar to those of the normal serum and mucus samples of the treated animals. Both of the heifers injected with rabbit semen exhibited serum and mucus titres of rabbit-sperm agglutinins of 1:1024 and $1: 256$, respectively, at insemination.

After repeated intra-uterine injection of semen and adjuvant, the two heifers with oviduct ligation produced antibodies to spermatozoa, as indicated by the presence of sperm agglutinins in the serum and mucus samples (Table 5). The 
serum titres fluctuated between 1:16 and 1:64 for both heifers following the series of five injections given 1 or 2 days post-oestrus. Mucus samples collected at oestrus had titres which were quite low and varied between $1: 4$ and $1: 16$. During the oestrus after the fifth injection, semen was introduced into the uterus with approximately $1 \times 10^{8}$ spermatozoa in $2 \mathrm{ml}$ of $\mathrm{N}-\mathrm{J}$ solution. Eight hours after insemination the animals were slaughtered and the uterine and oviduct contents were recovered by flushing with $\mathrm{N}-\mathrm{J}$ solution at $38^{\circ} \mathrm{C}$. Microscopic examination of the flushings revealed large numbers of polymorphonuclear leucocytes many of which were actively phagocytizing spermatozoa. It appeared that 40 to $50 \%$ of the sperm cells recovered were agglutinated, largely tail-to-tail, in numerous small clumps. The motility of the spermatozoa was $55 \%$ after recovery, compared to initial motility of $75 \%$ at the time of insemination.

\section{DISGUSSION}

These results indicate that in cattle, as in several other species, infertility can be induced in females by iso-immunization with semen and testis material. The intradermal route of immunization appeared to be more detrimental to fertility than intra-uterine injection, which was probably a result of the higher antibody titre produced by the first method. However, owing to the extra oestrous period allowed in the intra-uterine group between the last treatment and insemination, the average number of inseminations per conception could have been increased by nearly 1.0 if insemination had been started at the first post-treatment oestrus. The intervening oestrus was allowed so that the posttreatment inflammation could subside completely before insemination. Purulent vaginal discharges were frequently observed for 5 to 10 days after an injection. Examination of vaginal mucus samples obtained at first insemination gave no indication of a genital tract inflammation in the heifers injected by the intra-uterine route.

The antibody-enhancing effect of the adjuvant is well illustrated if this study is compared with the results of Kiddy, Stone, Tyler \& Casida (1959), in which only whole semen was parenterally injected in heifers. In the present trials, from 2 to $4 \mathrm{ml}$ of semen combined with an equal amount of Freund's complete adjuvant was injected into each animal, whereas Kiddy and his colleagues injected from 26 to $130 \mathrm{ml}$ of semen without achieving a noticeable effect on fertility.

The critical point at which fertility is interfered with following iso-immunization with semen or testis material has not been well demonstrated in the rabbit (Pommerenke, 1928; Behrman \& Nakayama, 1965) or the guinea-pig (Isojima et al., 1959; Katsh, 1959); however, in mice, McLaren (1964) reported that fertilization failure and not embryo mortality accounted for the infertility. Kiddy, Stone \& Casida (1959), using a heterologous system, observed that the treatment of rabbit spermatozoa with varying dilutions of a bovine antiserum resulted in fertilization failure and embryo death in the rabbit. Embryo mortality was also induced in 9-day-old rabbit embryos by direct contact with this bovine antiserum (Menge, Kiddy, Stone \& Casida, 1962). Menge \& Protzman (1967) indicated that, in the rabbit, there is at least one antigen not found 
in the blood serum that cross-reacts between semen and conceptus material. In the present study there were four diagnosed pregnancies lost in the treated animals. Interpreting prolonged oestrous cycles after insemination to mean early embryo mortality, as indicated by Hawk, Tyler \& Casida (1955), there were an additional seven possible embryo losses in four heifers, giving a total of eleven lost embryos in eight heifers. None of the thirteen control heifers experienced any detectable embryo mortality. Of the possible eleven mortalities, six losses occurred in four of the eighteen heifers iso-immunized by intradermal injection and five losses in four of the nine heifers injected by the intra-uterine route. In terms of the percentage of inseminations followed by embryonic death, the values were $0.0,6.7$ and 20.8 for the control, intradermal and intra-uterine groups, respectively. Other embryos may have been lost before the time when a prolongation of the return cycle would have resulted. A critical evaluation of the contribution of embryo mortality to the overall immunologically-induced infertility is needed in cattle and other species.

There appears to have been a fairly good, negative association between the serum titre of sperm agglutinins and the occurrence of pregnancy at the time of breeding. In general, conception occurred when the titres were 1:64 or $1: 32$ in the intradermally-injected group and $1: 32$ or $1: 16$ in the intra-uterineinjected animals. Similar associations of the level of circulating antibody to the antigens of testis and spermatozoa with infertility have been reported after iso-immunization with these respective materials in rabbits (Behrman \& Nakayama, 1965) and mice (McLaren, 1964). Conversely, Edwards (1964) failed to find any association of these factors after iso-immunizing mice with spermatozoa.

The large variation in the titres of sperm agglutinins in the vaginal mucus samples may be accounted for by the considerable fluctuation in the mucus secretion rates. Samples obtained during copious secretion of mucus at oestrus appeared to have the lowest antibody titres, suggesting a dilution effect. There have been conflicting reports concerning the passage of circulating antibodies into the genital tract of cattle (Pierce, 1953; Kerr \& Robertson, 1953; Kerr, 1955; Terpstra, 1956). The conflicts may arise partially because of a gradient phenomenon, in that unless the circulatory titre of antibody is high the amount of antibody in the secretions of the genital tract may be diluted to such an extent that it is difficult to detect. This appears to be the case in the present study, as antibodies to spermatozoa were detected in the uterine and vaginal secretions after intradermal immunization, but titres were generally less than half of the serum value.

The question of whether local antibody production against seminal antigens occurs in the tissue of the reproductive tract still appears to be unanswered. Kerr (1955) and Kerr \& Robertson (1953) reported that repeated inoculation of the uteri of cows with Brucella and Trichomonas organisms resulted in detectable antibodies in vaginal and uterine secretions but not in the blood serum, indicating a local antibody production in the reproductive tract. On the other hand, intra-uterine injections of cattle erythrocytes in heifers were reported by Kiddy, Stone, Tyler \& Casida (1959) to produce antibodies in the serum but not in the vaginal mucus, suggesting that the antigens passed into the circulation. 
In women, Straus $(1961,1965)$ detected specific vaginal antibodies after either local or parenteral immunization with typhoid antigen, but not after vaginal immunization with human seminal plasma. The relatively close association between mucus and serum titres of sperm agglutinins in the heifers injected by the intra-uterine route compared to the intradermal-injected animals suggests possible antibody production in the reproductive tract. The low antibody titre in the serum and mucus samples of the two heifers with ligated oviducts that received repeated intra-uterine injections of semen-adjuvant material does not support the local antibody production concept. It suggests systemic antibody production, in response to seminal antigens that enter the general circulation after absorption in the reproductive tract and the peritoneal cavity, to which the antigens gain access from the oviducts.

\section{ACKNOWLEDGMENTS}

This investigation was supported in part by a PHS Research Grant, GM11130, from Division of General Medical Sciences, United States Public Health Service. The technical assistance of D. Kramer and N. VanderWeide is gratefully acknowledged.

\section{REFERENCES}

Behrman, S. J. \& Nakayama, M. (1965) Antitestis antibody: Its inhibition of pregnancy, Fert. Steril. $16,37$.

Behrman, S. J., Otani, Y., Porter, C. W. \& Nakayama, M. (1963) Reduction of fertility in immunized guinea pigs. Int. F. Fert. 8, 835 .

Black, D. L., Duby, R. T. \& Riesen, J. (1963) Apparatus for the continuous collection of sheep oviduct fluid. 7. Reprod. Fert. 6, 257.

CASIDA, L. E. (1961) Present status of the repeat-breeder cow problem. F. Dairy Sci. 44, 2323.

EDWARDS, R. G. (1964) Immunological control of fertility in female mice. Nature, Lond. 203, 50.

HaWk, H. W., Tyler, W. J. \& Casida, L. E. (1955) Effect of sire and system of mating on estimated embryonic loss. 7. Dairy Sci. 38, 420.

Isojima, G., Graham, R. M. \& Graham, J. B. (1959) Sterility in female guinea pigs induced by injection with testis. Science, $\mathcal{N} . Y .129,44$.

KATSH, S. (1959) Infertility in female guinea pigs induced by injection of homologous sperm. Am. $\mathcal{F}$. Obstet. Gynec. 78, 276.

KERR, W. R. (1955) Vaginal and uterine antibodies in cattle with particular reference to Br. abortus. Br. vet. F. 111, 169.

KerR, W. R. \& Robertson, M. (1953) Active and passive sensitization of the uterus of the cow in vivo against Tr. foetus antigen and the evidence for the local production of antibody in that site. F. Hyg., Camb. 51, 405.

Kibrick, S., Balding, D. L. \& Merrill, B. (1952) Methods for the detection of antibodies against mammalian spermatozoa. Fert. Steril. 3, 419.

KIDDY, C. A., Stone, W. H. \& CAsidA, L. E. (1959) Immunological studies on fertility and sterility. II. Effects of treatment of semen with antibodies on fertility in rabbits. F. Immun. 82, 125.

Kiddy, G. A., Stone, W. H., Tyler, W. J. \& CAsida, L. E. (1959) Immunological studies on fertility and sterility. III. Effect of iso-immunization with blood and semen on fertility in cattle. F. Dairy Sci. 42, 110 .

McLaren, A. (1964) Immunological control of fertility in female mice. Nature, Lond. 201, 582.

MENGE, A. C., KIDDY, G. A., Stone, W. H. \& CASIDA, L. E. (1962) Immunological studies on fertility and sterility. V. Effect of antibodies against semen and erythrocytes on rabbit embryos. $\mathcal{7}$. Reprod. Fert. 4, 87.

Menge, A. C., Stone, W. H., Tyler, W. J. \& CAsida, L. E. (1962) Immunological studies on fertility and sterility. IV. Fertility of cattle and rabbits inseminated with semen treated with antibodies produced against semen, spermatozoa and erythrocytes. J. Reprod. Fert. 3, 331.

Menge, A. C. \& Protzman, W. P. (1967) Origin of the antigens in rabbit semen which induce antifertility antibodies. F. Reprod. Fert. 13, 31. 
Norman, G., Johnson, C. E., Porterfield, I. D., Goldberg, E. \& Dunbar, R. S. (1961) Prolonged maintenance of bovine sperm in a chemically defined diluent at ambient temperatures $\left(21-27^{\circ} \mathrm{C}\right)$. (Abstract). 7. Dairy Sci. 44, 1180.

Pierce, A. E. (1953) Specific antibodies at mucous surfaces. Proc. R. Soc. Med. 46, 785.

Pommerenke, W. T. (1928) Effects of sperm injections into female rabbits. Physiol. Zoöl. 1, 97.

Straus, E. K. (196I) Occurrence of antibody in human vaginal mucus. Proc. Soc. exp. Biol. Med. 106, 617.

Straus, E. K. (1965) Sperm immobilization in the human vagina by induced muco-antibody. Fert. Steril. 16, 346.

Terpstra, J. I. (1956) Some aspects of genital infections in cattle. Proc. IIIrd int. Congr. Anim. Reprod., Cambridge, Plenary papers, p. 34.

WeIL, A. J. \& Roserts, G. O. (1965) Fertility of female rabbits after iso-immunization with seminal plasma. Fert. Steril. 16, 356. 